\title{
Ethnologies
}

\section{Critical Literacy and the Un/Doing of Academic Discourse}

\section{Catherine G. Taylor}

Volume 26, numéro 1, 2004

\section{Littératie}

Literacy

URI : https://id.erudit.org/iderudit/013343ar

DOI : https://doi.org/10.7202/013343ar

Aller au sommaire du numéro

\section{Éditeur(s)}

Association Canadienne d'Ethnologie et de Folklore

ISSN

1481-5974 (imprimé)

1708-0401 (numérique)

Découvrir la revue

Citer cet article

Taylor, C. G. (2004). Critical Literacy and the Un/Doing of Academic Discourse. Ethnologies, 26(1), 125-143. https://doi.org/10.7202/013343ar

\section{Résumé de l'article}

Cet article décrit l'utilisation de l'approche " littératie critique » dans un cours de premier cycle en écriture académique enseigné à un groupe d'étudiants socialement marginalisés par la pauvreté et les préjugés. Dans cette approche, l'auteure demande aux étudiants d'identifier des domaines de recherche qui les intéressent personnellement en se basant sur leur propre vie pour générer des sujets significatifs, de s'engager dans un dialogue critique au sujet de leur travail, ainsi que d'écrire dans un style académique sans se couper de leur travail. Elle accueille aussi les observations critiques des étudiants sur leur propre expérience de la culture dominante et les invite à scruter le monde universitaire dans lequel ils entrent en tant qu'institution qui participe pleinement aux systèmes de privilèges et de pouvoir. D’après son expérience, la plus grande partie du travail réalisé par ces étudiants engagés dans une telle approche a démontré un degré plus élevé d'esprit critique et de construction sérieusement fondée de la connaissance qu'on ne le voit d'ordinaire dans un cours d'écriture de premier cycle. Elle argumente une analyse raisonnée en faveur de l'utilisation de cette méthode fondée sur l'autonomisation pour enseigner l'écriture académique, à l'opposé des appels à un retour aux méthodes traditionnelles, en produisant une analyse centrée sur la théorie de la littératie critique pour rendre compte de ses succès et de ses défis.
Ce document est protégé par la loi sur le droit d'auteur. L’utilisation des services d'Érudit (y compris la reproduction) est assujettie à sa politique d'utilisation que vous pouvez consulter en ligne.

https://apropos.erudit.org/fr/usagers/politique-dutilisation/ 


\title{
Critical Literacy and the Un/Doing of Academic DisCOURSE
}

\author{
Catherine G. Taylor \\ Centre for Academic Writing, University of Winnipeg
}

Critical Literacy emphasizes reading and writing as activities for personal empowerment and social transformation. Paolo Freire (1987), the great Brazilian educator who founded the critical literacy movement, described the critical use of language which he hoped his adult literacy students would embrace as "reading the word and the world." Like others working in the field of critical literacy, he saw the process of becoming literate as a consciousness-raising project in which one becomes aware of how language powerfully structures our experience of the world, enmeshing our every perception and feeling in pre-existing value-laden systems of meaning that help to legitimize existing social arrangements. People who are becoming "literate" in the ordinary sense of the term are learning to recognize what words stand for, to look right through words at the world. In contrast, people who are becoming "critically literate" are also learning not to look through words at the world; they are learning instead to see the words - Freire's "wordworld" - themselves. They are coming to recognize that language is not a neutral transmitter of reality, best wielded by those with the best education, but a political arena where established practices and conventions serve dominant members of society in an intimate clutch described by Michel Foucault (1980) as "power/knowledge."

Critical literacy, it could be said, means waking up to the status of dominant language practices as the servant of power. It means recognizing how texts participate in "discourses" in the Foucauldian sense of dominant language systems that structure the forms and limits 
of possible thought, making it difficult for any text expressing nondominant views to be persuasive or appear rational (Foucault 1982). Working with illiterate peasants in Brazil whom he saw as terribly exploited by a wealthy landowning class, Freire saw that if literacy were truly to make good on its promise of hope for a better life, learning to decode the word would need to mean far more than learning to read and write. Students would have to learn to decode the political nature of language: exposing how injustice and vested interest are legitimized in it, how it teaches marginalized people to feel inferior and hopeless. It would mean struggling against the oppressive weight of dominant discourses to articulate desires for a better world and communicate them with potential allies (Gale and Dunsmore 2000).

Critical literacy has evolved from its roots as a politically-inflected method of teaching basic reading and writing skills. The literature of critical literacy has by now become well-developed in Canada, Australia, the U.S., and Britain by scholars such as Barbara Comber, James Paul Gee, Barbara Kamler, Henry Giroux, Colin Lankshear, Allan Luke, Chris Searle, Ira Shor, and Wendy Morgan, to name some of the most prominent. Critical educators currently use it across the curriculum and throughout educational levels as a method of teaching alreadyliterate people how to think critically about language and perhaps spark a passion for social change. However, critical literacy does not have broad-based popularity among teachers except in media studies (where students are taught to see the destructive social engineering at work in such media representations as skeletal young women and logoemblazoned young men) and information technology studies (where students are taught to scrutinize web texts for authority, accuracy, and so on). Outside these areas, critical approaches to teaching remain somewhat suspect not only politically but practically. Critical literacy is not widely employed in the teaching of subjects such as literature or history, for example, even though the canonical tendency of both these subjects lends them easily to a critical approach. The common charge is that critical approaches are not practical; that they ignore essential skills to pursue a leftist social agenda at the expense of the students who are entrusted to their teacher's care. (The response made by critical educators and myriad educational sociologists is that uncritical approaches pursue a profoundly conservative one at the expense of non-mainstream students. See, for example, Apple 1993, 1995.) 
In this paper I reflect on my own experience of using a critical literacy approach to teach a course in Academic Writing that is charged with the practical mandate of equipping socially marginalized students with rocky educational histories to write university essays in a range of subjects. I argue that my students became successful in doing this precisely because of, not in spite of, the critical overlay of the course, and I hope to provoke other teachers to consider the practical advantages of a critical literacy approach in their own classrooms. Although my focus in this article is on its pedagogical strength for socially marginalized students, critical literacy is also an important approach to teaching privileged students, both on the principle that developing critical consciousness is personally liberating to all of us, and on the one that the world needs more privileged people to develop a passion for social change.

Critical literacy works in marginalized contexts because it is inspiring to students who are weary of occupying abject positions in the education system or struggling against poverty and prejudice. Instead of disqualifying their life-experience as irrelevant to academic work, the curriculum is designed to make direct use of their experiences of social injustice and misrepresentation, and makes room for the expression of critical insights that are genuinely impressive intellectual achievements but seldom heard because seldom invited outside critical classrooms. As Ira Shor has pointed out, critical literacy is grounded in the personal and embraces the political in the interests of "remak[ing] our selves and society, if we choose, through alternative words and dissident projects. This is where critical literacy begins - words that question a world that is not yet finished or humane" (1999: 1). The bold, affirming, hopeful spirit of critical literacy can appeal strongly to a range of people, whether personally disadvantaged or not, who find the world unjust, and educators have applied the disruptive, rebuilding methods of critical literacy to surface the voices and perspectives of people occupying a wide range of subjugated social identities in what bell hooks (1997) has called the "white supremacist capitalist patriarchy" of the Western world: among them, people of colour, people living in poverty, girls and women, and gay/lesbian/bisexual/transgender/two-spirit/queer people. If, as Shor hints, not everyone who is oppressed will want to become a social activist, critical literacy can still function as a path to becoming functionally literate so as to make one's way in the world as it is. 


\section{Critical Teaching}

In the summer of 2001, I prepared to teach a year-long Academic Writing course in an access program where inner-city residents were enrolled in a B.A./B.Ed. program designed to prepare them to teach in inner-city schools. Here was a scene of critical teaching where the stakes were very high: students who graduated from the program would become teachers and important role models who brought experience of the inner city to their work with children. The program is housed in an unconverted elementary school building with child-height sinks, fountains, and toilets; comically loud radiators and no air conditioning; undrinkable water; and a tiny library, a long bus ride involving several transfers to the nearest university library. Any critically literate person accustomed to the surroundings of most mainstream university programs might read this architectural text — as Pat Capponi observed of the miserable waiting rooms in social assistance offices (Waite 2002) - as signifying that those judged to be the least significant people had once again been stuck into the least significant space. As the program's informational brochure describes, the "student body reflects the demographic make-up of the core area (First Nations, visible minorities, recent immigrants, and others)," where "others" includes, in a rare lexical choice, able-bodied Canadian-born white people. The program is

designed to provide a university opportunity for adults with inner city experience who would not normally be able to enter and succeed in university because of financial, academic, or social needs. Examples of such needs include the following: low family income, single-parent responsibilities, minority racial/ethnic status, and lack of prerequisite academic qualifications (University of Winnipeg Education Centre/ UWEC Program brochure 2002).

All of my students turned out to be women, most of them single mothers, many of them First Nations and Métis in an ethnically diverse but white-dominant city where poverty is undeniably organized around the Aboriginal "racial" axis. My own social location had acquainted me thoroughly with forms of oppression specific to gender and sexuality, but I am a white professor in a white-dominant culture, currently middleclass and many years removed from financial hardship, and I have never been targeted by racism. I expected that my students would be people who knew at least as well as I that the "world is not yet finished or humane," as Ira Shor puts it (1999), and who had personal reason to invest in critical literacy's project of social transformation. 
But I also knew that my students would be people enrolled in an educational institution who would need to develop functional academic literacy to survive there. Whatever pedagogical approach I worked from, critical or not, the course would need above all to introduce students to the methods of academic writing that they are expected to practise in their university courses. It would be crucial to cover the main elements of academic argumentation: representing outside sources through summary, paraphrase, and quotation; criticizing sources; research methods and documentation; all of which are pulled together in an argument-style research essay at the end.

Even for mainstream students with strong high school grades, the first encounters with scholarly prose can be intimidating, boring, almost physically repulsive: characterized often by long paragraphs, polysyllabic Latinate language, fetishistic suppression of emotion, no illustrations except unreadable graphs, produced by people with Ph.D.s, it is a wordworld that is not their own, and does not welcome outsiders. For most of my students, many of them ten years out of high school, or having finished their high school in adult education courses, academic writing is unknown territory and a very unwelcoming one at that. They are the least significant people in that territory in terms of authority and expertise; the people who show up as subjects of academic studies, not authors of them.

Knowing how academic prose can marginalize people occupying my students' social positions, teaching them that they are unqualified to speak, I had considered downplaying the mastery of academic genres as an end in itself, and instead emphasizing the development of a writing voice in which to communicate with "real" audiences of one's own choosing about subjects of personal importance. At one point I considered a life-writing and autobiography focus, and would happily have facilitated writing in whatever form - journals, poetry, news and opinion pieces, etc. - would afford the experience of writing as a worthwhile activity that helps to accomplish something of value; the mastery of academic methods could follow. I ultimately rejected these indirect approaches because Academic Writing is a subject firmly defined by its service to purposes beyond itself that constrain pedagogical goals and choices: coming to love writing or see it as critical to oneself is secondary to the goal of achieving the functional literacy needed immediately to survive elsewhere in academia. A critical literacy approach to the course could center academic prose yet offered an 
impertinent scrutiny of dominant culture and profound respect for intellectual empowerment to counterbalance its oppressive effects.

As I planned the course, I chose a handbook that would cover the main elements of academic writing, and then looked for a reader that would offer a stimulating set of topics for class discussion and student assignments. To do this, I tried to imagine who my students would be and considered several quite promising books that I could predict would be relevant to their present and future lives: collections on issues of social diversity and social justice, collections related to Aboriginal peoples in Canada, collections on progressive teaching methods. Deciding against presuming to know my students before I'd met them, and in keeping with Shor's (1992) "generative" method of teaching writing, I instead trusted my students as adults to chart their own learning path. I began the course with a handbook but no reader and counted on dialogic work with my students to generate topics of collective concern grounded in their own lives, for which I could find and photocopy readings or provide URLs. Our course began on September 12, 2001, the day after the terrorist attacks on New York and Washington. Like thousands of other courses that began that September, ours was dominated by those events, the bombing of Afghanistan that ensued, and the changed world and word-worlds that were emerging in their wake. If I had presumed to offer a fixed reading list, September $11^{\text {th }}$ and its aftermath would surely have derailed it.

In the text that follows I reflect on how critical literacy worked in our class to help my students develop sound academic writing abilities. I focus most intensively on the work of one student, Chelsea Waite ${ }^{1}$, as a way of demonstrating the developmental model we followed in the course: not one of deficit-repair predicated on their lack of academic experience, but one predicated on the critical abilities they had already developed.

1. I wish to thank all my students for consenting to let me document our class discussions and analyze our experience together. Their hard work and generous spirits enriched my life and my experience as a teacher. I am especially grateful to Chelsea Waite for agreeing to let me quote her work at length. I asked Chelsea for permission to make more intense reference to her work because it consistently demonstrates what was often found in all my students' work: the application of critical thinking and the struggle for academic voice that characterized our work in this course. 


\section{"Reading the News"}

In our first class I distributed a set of news clippings and a list of questions headed "Developing Critical Perspective by Getting Outside the Box." Such questions are commonly used in critical literacy courses to draw attention to texts as constructs that frame reality in ways that reflect the political biases of the speaker, and in so doing serve some people's interests and harm others':

- Who benefits from the way this story is told?

$0 \quad$ Who's telling the story? What difference does that make?

$0 \quad$ Whose voices are heard, and whose aren't? What difference does that make?

0 What relevant factors are missing? What difference does that make?

0 What kind of evidence is offered? What kind of evidence is not offered?

- What is treated as a root cause? Who benefits from that?

$0 \quad$ What is left until the end (when most readers have stopped reading) or barely acknowledged?

- How else could this story have been told? What difference would that make?

Answering such questions requires sophisticated skills in rhetorical analysis that mainstream students even in senior years of university study often struggle with. In using it to launch the course, I was working from the premise that my students may not have had equitable opportunities to develop the critical reading skills practised in academic subjects such as literature, but that their marginalized social locations as inner-city women would have provided ample opportunity to develop skills in reading the word-world critically. Along with the questions I distributed a set of news clippings that included a front-page Globe and Mail article titled "Ottawa Pulls Plug on Native Junketeers," a CP article called "Researchers Seek Smelly Solution to Gas-Sniffing" that appeared in the Winnipeg Free Press, and three articles from that newspaper: a "Crime Stoppers" story featuring mug shots and bios of young Aboriginal women wanted mainly for shoplifting offences but titled "Police Officers Hurt on Woman's Day of Rage," a story about the lack of qualified applicants in downtown Winnipeg: "Help Wanted — and Lots of It: Stores Bemoan Slim Pickings at Mall Job Fair," and "Special Teaching Planned for Fetal Alcohol Sufferers" (Paul 2000). 
This last article described a pilot project being launched to support teaching children with Fetal Alcohol Syndrome (FAS), a condition defined in the article as "profound learning disabilities caused by their mothers drinking during pregnancy." The article explains that the pilot project would be run in inner-city Winnipeg schools and comments on Manitoba's high rate of FAS, especially in rural and northern areas. It winds up with comments from elected officials who express a desire "to ensure that teachers and aides have information on the best strategies for teaching children with FAS" and reclaim students who would otherwise likely become "young adults who have had serious run-ins with the law."

I excerpt parts of Chelsea Waite's response below as representative of the critical acumen and rhetorical skill this young woman brought to our first class.

Who benefits from the way this story is told? What difference does this make? I strongly feel that this article benefits the Winnipeg School Division and the Government of Manitoba. It makes them out to be heroes. When realistically steps should have been taken towards resolving these problem years ago. The difference this makes is that we direct our attention to the wrong people. Instead of concentrating on the real heroes (the children with FAS), we're concentrating on our heroes the school system and the Government. Which I think is a wasted effort!

Whose voices are and aren't heard? What difference does that make? Again I feel the school divisions voice is strongly heard. While the people it affects, while their voices are mute! Also I've noticed a whole ethnic group is also mute. The Aboriginal culture that is. This article seems to be very repetitive in stating that the Aboriginal people are an ethnic group, which has many cases of FAS. So it's funny they didn't talk to a group of Aboriginal parents so they may voice their opinions. Isn't that ironic!

What is treated as a root cause? Who benefits from that? I feel that the Aboriginal people are being treated as a root cause. Quotes "Rural and Northern Manitoba is ten percent" and "Forty percent in the Yukon and North West Territories." Boy I didn't realize that only Aboriginal children only had FAS, Ha Ha! Throughout the article they've made sure to mention that the highest percent of children with FAS are in the Northern communities... 
What is left until the end (when most readers have stopped reading), or barely acknowledged? They've left a very important fact to the end of the article. What has been happening to these children before this program? They casually mention I quote, "We know full well what not being sensitive has resulted in with young adults who have had serious run-ins with the law." Well they certainly are trying to run that bout of shame past us quickly. I want to know how much have these children been suffering? How has having FAS affected their adulthood? How much support was offered previously to them? How much crime is committed because of children with FAS? How well we tend to throw out serious facts so casually...

Chelsea and the other students who responded with similarly astute observations had clearly arrived in class with the impressive critical reading skills they displayed in this assignment; the critical-literacy aspects of the assignment that drew on their experience of marginalization instead of attempting to compensate for it only allowed these skills to become visible in the classroom. My students were alert to the precise moments at which textual omissions, elisions, and deemphases had the effects of silencing marginalized groups and shifting much needed attention away from their concerns to get on with the business of glorifying those already dominant in society. They identified precisely the textual constructs that missed or misrepresented the actual root causes of problems to shift blame from dominant culture to its victims.

When I use this exercise in mainstream academic courses, and in fourth year education courses, there is of course a range of performance, but unless they had already developed critical alertness to what Ludwig Wittgenstein (1967) called "language games" through prior social or academic experience, students in those settings have tended to miss the rhetorical dimensions of the texts under analysis. For example, instead of noting the social power plays identified by Chelsea, they might focus on the lack of specifics about how the grant money would be spent, or wonder whether the information given in the article had been fact-checked. In contrast, most of the students in my group of inner-city adults demonstrated a high degree of textually alert, critically astute analysis, though not always in acceptably academic grammatically polished style. Because of their generally checkered, interrupted school backgrounds, these same students might have seemed less accomplished than their mainstream peers if asked to analyze Shakespeare. "Reading the News" is an example of a "situated" approach to making room for 
marginalized people simply by drawing on their social context and life experience, so that they can demonstrate their critical abilities, rather than presenting them with textual territory that might be familiar to mainstream students straight out of high school but quite alien to them. Their performance on this assignment showed my students and me that they were well situated to develop academic literacy.

\section{Reading the University}

A crucial distinction between the version of critical thinking enshrined in traditionalist forms of the liberal arts on the one hand, and that advocated in critical literacy (and more broadly in critical social theory) on the other, is that academia speaks as the authoritative, originary voice of critical thinking in the former and is subjected to critical scrutiny as a politically invested institution of dominant culture in the latter. In a second exercise in critical reading I asked students to deconstruct a list of such statements as the following that had been made and passionately defended as true by mainstream institutions, often by academics:

- Interracial dating or marriage should not be allowed at Christian colleges.

- Women should not be allowed to vote or hold political office because they lack the rational capacities of men.

$0 \quad$ It is acceptable to enslave people of other races because slavery helps the white race to prosper and spread Christianity worldwide in accordance with God's plan.

- Women should not attend university because studying diverts energy from the uterus.

- Parents should discourage gay or lesbian orientations in their children to save them from a future of social discrimination.

My students already understood that a variety of mainstream institutions such as the media, social services, and law enforcement were biased against socially marginalized people, but some students expressed shock that such blatantly oppressive beliefs had been defended by academics. The exercise of identifying whose interests were served by these beliefs provoked a discussion of how universities have traditionally performed the roles not only of disinterested truth seeker and fearless critical thinker, but also of guardian of civilization (Pelikan 
1992), and how the third role might exert brakes on the first two in a civilization structured along lines of race, class, gender, and other social differences. The practice of "self-subversive self-reflection," in Shoshana Felman's (1987) term, has become axiomatic to anti-oppressive critical thinking in a diverse world where we recognize that texts are always partial, invested, and guilty of sacrificing something in the interests of achieving something else (Foucault 1984). Knowing how much damage has been done in the name of scholarship - damage to women, to Aboriginal people and people of colour, to people living in poverty, to name only the identities most prominent in my class - it becomes ethically questionable to offer up any body of knowledge without careful scrutiny of its "forms and limits." At the same time, it is important to acknowledge that important contributions can be made through academic work. As the critical multicultural educator James A. Banks reminds us,

[s]tudents can analyze the knowledge construction process in science by studying how racism has been perpetuated in science by genetic theories of intelligence, Darwinism, and eugenics... Although science has supported and reinforced institutionalized racism at various times and places, $[\ldots][b]$ iological theories and data that revealed the characteristics that different racial and ethnic groups share, and anthropological theory and research about the universals in human cultures, have contributed greatly to the erosion of racist beliefs and practices (1994: 10).

Our subversive but balanced discussion was empowering for my students as they proceeded with their initiation into academic literacy. Recognizing that scholars, despite their intimidating credentials, were capable of grave error usefully demystified the infallible authority of the institution for my students as people positioned at its lowest rank. More importantly, recognizing that their voices were extremely rare in academia, and that their continued under-representation in the knowledge-production process was dangerous to marginalized people, they had clear demonstration of the extreme importance of their attaining academic literacy and contributing their voices to an institution still badly in need of diversification.

\section{Representing Others Accurately}

A continuing theme running through students' analyses of mainstream institutions (the news industry and academia) was the damaging real-world effects of misrepresentation and the wide range of 
social power-plays involved in who and what gets represented and misrepresented. The intense indignation displayed in Chelsea's comments on the reporter's failure to include the voices of people with FAS proved pivotal to our next assignment, one that involved summarizing short articles. Accurate representation of others' work in the form of summaries, paraphrasing, and quoting, is crucial to academic literacy: scholars need to represent others' ideas accurately in order to draw solidly on the work of similarly fastidious colleagues and thus contribute to the accumulation of scholarly knowledge. But because it demands rigorous suppression of one's own opinions, the work of representation can be experienced by students as a dull, mechanical, yet difficult activity. This is particularly the case if the material assigned seems to be a mere schoolroom text irrelevant to their sense of what is important. The decision not to adopt a reader and instead find articles related to themes identified as important by the students proved useful at this time. The attention of my students was riveted on the events of and ensuing from September 11, 2001, and like many others they were also interested in understanding the larger political context in which the attacks occurred.

In order to provide a clearly meaningful exercise in representing others accurately, I asked students to summarize a speech made by Sunera Thobani (2001), former President of the National Action Committee on the Status of Women and currently a University of British Columbia professor of Women's Studies. In her speech, Thobani expressed compassion for the thousands murdered in the attacks, but questioned why we in the West seem indifferent to the deaths of people in the Middle East, and warned that the rhetoric of war being mobilized by President Bush reflected a long racist history. Thobani had been given a standing ovation for her speech at the Anti-Violence Conference in Ottawa a few days after September 11, but she had also been bitterly denounced across the country for having seemed to accuse the U.S. of bringing the attacks on itself by racist behaviour. Here there was no hint that the task of representation was dull or easy. With the smoldering towers still dominating the news, and the rhetoric of war building, students took the task of summarizing Thobani extremely seriously. They worked hard, together, to suppress their own judgements on American foreign policy and avoid second-guessing her motives so that they could develop summaries that accurately and fairly represented what she had actually said. At times twenty minutes would be spent in 
vigorous debate over the choice of a few adjectives as students strove to ensure that Thobani's voice, and not theirs, would be heard in their work. In this assignment, representation, often experienced as the humblest aspect of academic literacy, seemed "critical" indeed, invoking the highest ethical ideals of respect, justice, and principled use of power. The experience of life at the margins of society that surfaced so powerfully in critical skill in these students' first assignment to deconstruct the news was equally evident in their ready commitment to respecting the integrity of Thobani's text as that of another soul in struggle and in danger of misrepresentation.

My students went on to summarize many other texts related to our emerging theme of "women and peace," meeting each one with equal responsibility and diligence. Far from being a distant shore from which they had to swim in order to enter academic territory, their experience of life at the margins was proving to be an extremely valuable resource in the path towards academic literacy. When we turned from summarizing texts to critiquing them, their work continued to show the skeptical diligence appropriate to issues where lives were at stake: Does $\mathrm{X}$ get it right? Would her approach help us to avoid another genocidal national project? Is Y accurate in her prediction that supporting women's collectives in African countries would ultimately promote peace? Is Z's term "Two-Thirds World" a useful intervention in political studies? They were not only thinking hard, but doing so less as novice students than as concerned citizens whose experiences of marginalization had enhanced their ability to contribute to dialogue about important social issues.

\section{$\mathrm{Re} /$ Searching for Peace}

As the weeks went on, students kept calling attention to the silencing of women, first by the sexist Taliban regime and then by virtually complete exclusion from the post-9/11 response. Students often made parallels to the situation of women in our own communities and more broadly in Canadian government and other decision-making bodies, and spoke of their own experience of women struggling to resolve conflicts in their homes and communities. I had asked students early on to work towards a theme worth devoting our collective intelligences to investigating in research essays, and by November we recognized that all our interests could be understood as aspects of “women's 
contributions to making peace." From that point we read many scholarly articles written by women writing from marginalized locations around the world. In keeping with the constructive aims of critical literacy, we built on our deconstructive analysis of mainstream texts by reading and writing texts from the margins that struggled to create grounds of hope.

Dialogue in the class became continuously richer and more complex as the course developed and students started to define individual research topics within the broad theme we had generated of women and peace. We agreed that individuals should try to find a topic related to the theme, so that they could build on the thinking they had been doing all year and benefit from interconnections with each other's topics as the process of research and writing continued. We also agreed that individuals should be free to interpret the theme broadly rather than restricting themselves to women's involvement in anti-war efforts; everyone, however, should be able to explain to the group how her own topic related to the theme, and how researching it would contribute to her development as a future inner-city teacher. They chose sexual exploitation of children in inner-city Winnipeg, living in the burq'a, living with FAE/FAS, surviving incest, the Battered-Women's Syndrome as a legal defence, homophobia experienced by the children of gay and lesbian parents, women in the Holocaust, women's roles in Métis culture and history, and the overmedication of women for mental disorders. In each case students had personal connections to their topic, either directly or in their communities, and were committed to constructing rigorously researched arguments in support of their various commitments to peacemaking. Most of them also did primary research by interviewing people who were directly involved in the issue. When they submitted their essays near the end of the course, I was deeply impressed by their success at harnessing the conventions of academic literacy in the service of intellectual projects of intense personal concern.

Chelsea decided to conduct research into the topic of "Women and the Welfare System: the Struggle Through Poverty." Throughout the course Chelsea's work had been consistently strong in every academic sense - accurate representation, critical depth, scholarly research, logical analysis - save one: her intense engagement with her work often erupted into a highly conversational writing style that I always enjoyed but that detracted from her scholarly effectiveness by seeming to privilege sarcasm over careful explanation. I had worked with her 
on passages such as "Boy I didn't realize that only Aboriginal children only had FAS, Ha Ha!" and her writing had become much stronger academically as she trained herself to see such interjections as candidates for revision.

The essays of all the students had many strengths, yet I want to quote Chelsea's introduction in full before closing. It is, first, rhetorically powerful, employing her conversational tone in a bold personal address to the reader, and then authoritatively shifting to a sobre academic style she sustains for the entire argument. It also exemplifies the quality of work these students were able to achieve by working through a critical literacy approach that never asked them to transcend themselves as a condition of academic work.

$\mathrm{Hi}$, my name is Chelsea Waite. I am twenty-one years old and a single mother of a two-year-old daughter, named Hannah. I use the services of Welfare; therefore I abuse the services of Welfare. Logically I am lazy and I like to drink and do drugs with my welfare check. I neglect my child; basically allowing her to run wild. I leave my child in a filthy condition so that I do not miss any of the bingo games. My goal is to have at least five more kids so that my elaborate welfare check gets even bigger. I never intend to work, why should I? I am living large. After all is that not what taxpayers are good for?

Although these are common misconceptions about the recipients of welfare, my goal here is to dispel these disturbing myths. I intend to concentrate on what are the real reasons women turn to the services of the much hated welfare system. I would also like to focus on what we can do as a society to end this cycle of poverty. It is not just out of frustration that I will dispel these myths, but I know it is essential if we are to understand the vicious cycle of poverty (McDermott 1$)$. What possibly could drive these women to a life of isolation, poverty, and constant judgment from members of society? This topic is of extreme importance to me, as I feel the voices of those struggling in poverty need to be heard loud and clear. The solutions that are made available to welfare recipients at this time are ineffective. In other words, I know we as a society need to find these solutions before the cycle of poverty consumes all of our future generation...

On the last day of the course, students shared with each other the arguments they had made in their research essays. As they described their results, they referred to appropriate scholarly support for their claims, but one after another called for government and academics to listen to the voices of women who felt trapped in the social assistance program, of children taunted by homophobic insults, of adolescent girls 
who end up as street workers. In so doing they showed that they were equipped with a critical approach to academic literacy that authorized their own experience of the world and sharpened their insight into the political biases of scholarship and other social institutions. These women are going forward into their next courses with a well-developed conviction that they can contribute what academia too often lacks: the passionate expression of their own "subjugated voices" in the cause of improving life for those who are oppressed by the existing power arrangements of our society.

\section{Conclusion}

The learning path my students forged to take their place in academic discourse was not invented by us; it can be traced back to John Dewey's $(1916,1938)$ theorizing of a democratic education system grounded in and enlarging experience that would enable all to participate in a common life, and W.E.B. DuBois' (1902) struggle to develop curricula for African-American students who were systematically degraded and erased and consequently performed poorly in a school system that was devoted to extolling the achievements of white culture. Huge efforts have been made since the 1960s to understand the performancedampening effects of monocultural schooling and to develop alternate approaches that would better facilitate the achievement of excellence by students from non-dominant social locations. In these times of renewed calls for a return to the basics, the empowerment-based pedagogies that were developed in the interests of allowing more students to achieve academic excellence are routinely lampooned as a flaky and misguided modern trend. A false incompatibility is perniciously asserted between the goals of empowerment and those of academic literacy, as though in aspiring to the former one is blithely or even perversely neglecting the latter. Exhortations for a return to the standardized curriculum and standardized testing are made alongside demands for career-long assessment of teachers' competence, by which is pointedly not meant pedagogical strength, but mere knowledge of the content area and how to transmit it. Comments such as the following, extracted from an op-ed piece arguing for abolishing the B.Ed. as a requirement for teacher certification, are typical. Freed from that requirement, the author argues, 
[S]chool boards and principals (...) would be hiring from a larger pool of candidates, some of whom also have been spared the many orothodoxies [sic] in teacher education programs, particularly the obsession with moulding self-esteem instead of achieving academic excellence (Holle 2002).

A critically literate reader of Peter Holle's article might well ask, "How are the interests of dominant culture served by defining curriculum as standardized content? By asserting an antagonism between pedagogy and curriculum? By reducing the attempt to foster respect for ethnic, class, and gender diversity in student teachers, and reflect it in the curriculum, to an obsession with 'self-esteem'? At whose expense? Who stands to gain, and who to lose, if we dismiss empowerment-based pedagogies as 'fluff'?"

When the goal is academic literacy, there is no mistaking mere selfesteem for empowerment, because empowerment in an academic context requires the development of good reason for confidence in one's intellectual rigour, exercise of analytical faculties, and production of compelling argumentation. For the students whom it has been my great privilege and pleasure to teach, the pursuit of critical literacy has served as an empowering path towards academic literacy, not an aberrant course away from it. The educator charged with the responsibility of preparing students to meet the demands of academic writing might well take a critical look at the political interests behind the access versus excellence rhetoric of current discourse, and feel academically entitled to choose both: as so often is the case in the polarized debates, the best course can be to choose "not between, but of," to choose "the things that in each other are included" (Stevens 1942). In the context of academic writing for students who inhabit spaces outside the social mainstream, that means choosing access and excellence, empowerment and literacy. A critical approach to literacy that begins where students live provides an effective and pedagogically coherent way of making that context-respectful decision not to abandon one goal out of loyalty to the other. 


\section{References}

Apple, Michael. 1993. Official Knowledge. New York: Routledge. 1995. Education and Power. New York: Routledge.

Banks, James A. 1994. Multiethnic Education: Theory and Practice. (3 ${ }^{\text {rd }}$ Edition). Needham Heights (MA): Allyn and Bacon.

Dewey, John. 1966 [1916]. Democracy and Education. An Introduction to the Philosophy of Education. New York: Free Press.

Du Bois, W. E. B. 1999 [1903]. The Souls of Black Folk. Chicago: A.C. McClurg \& Co; http//:www.Bartleby.com/114

Felman, Shoshana. 1987. Jacques Lacan and the Adventure of Insight: Psychoanalysis in Contemporary Culture. Cambridge (MA): Harvard University Press.

Foucault, Michel. 1984 "On the Genealogy of Ethics: An Overview of a Work in Progress." In Paul Rabinow, ed., The Foucault reader. New York, Pantheon: 340-372.

Language. New York: Pantheon.

-1980. Power/Knowledge: Selected Interviews and Other Writings 1972-1977 (Colin Gordon, ed). New York: Pantheon.

Freire, Paolo. 1987. "The Importance of the Act of Reading." In Paolo Freire and Donaldo Macedo, eds., Literacy: Reading the Word and the World. Westport (CT), Bergin \& Garvey: 29-36.

Gale, Trevor and Kathleen Densmore. 2000. Just Schooling: Explorations in the Cultural Politics of Schooling. Buckingham (UK): Open University Press.

Holle, Peter. 2002, June 10. "What Is 'Qualified' Schoolteacher?" Winnipeg Free Press A11.

hooks, bell. 1997. Cultural Criticism and Transformation. [Video recording]. Northampton (MA): Media Education Foundation.

Paul, Alexandra. 2000, September 9. "Special Teaching Planned for Fetal Alcohol Sufferers." Winnipeg Free Press, A4.

Pelikan, Jaroslav. 1992. The Idea of the University: A Reexamination. New Haven: Yale.

Shor, Ira. 1999. "What Is Critical Literacy?" In Ira Shor and Caroline Pari, eds., Critical Literacy in Action: Writing Words, Changing Worlds. Portsmouth (NH), Boynton/Cook: 1-30. 
1992. Empowering Education: Critical Teaching for Social Change. Chicago: University of Chicago Press.

Stevens, Wallace. 1942. Notes Toward a Supreme Fiction. Cummington (MA): Cummington Press.

Thobani, Sunera. 2001, October 3. "Colonized in the Name of the West." National Post. http//:www.nationalpost.com, October 5, 2002. Waite, Chelsea. 2002. Personal communication.

Wittgenstein, Ludwig. 1968. Philosophical Investigations. Oxford: Basil Blackwell. 
